\title{
Do Foreigners Control the U.S. Money Supply?
}

\author{
GEOFFREY E. WOOD and DOUGLAS R. MUDD
}

. HERE have recently appeared claims that developments in the Eurodollar market have contributed substantially to the current expansion of the U.S. money supply $\left(\mathrm{M}_{1}\right) 1^{1}$ These claims imply that the Eurodollar system is a source of monetary disturbances which the Federal Reserve System cannot offset. On the basis of these claims, it is sometimes then asserted that the recent weakness of the dollar in foreign exchange markets has been due to an expansion of $\mathrm{M}_{1}$ caused by transactions in the Eurodollar market.

In fact, the extent to which transactions in the Eurodollar market can affect $M_{1}$, and thereby make more difficult the Federal Reserve's task of monetary control, is at most very small. Futher, any effect on $M_{1}$ from Eurodolkar transactions an be fully offset by Federal Reserve actions. Therefore, if Eurodollar transactions do affect $\mathrm{M}_{1}$, it must be with the concurrence of the Federal Reserve System.

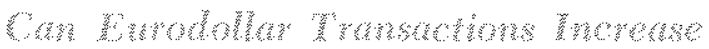

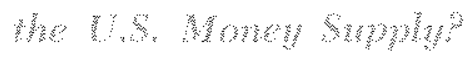

Eurodollar deposits are dollar-denominated deposit liabilities of banks, including branches of U.S. banks, located outside the U.S.2 These dollar-denominated

1See, for example, "Economic Dary: Solving the Riddle of Monetary Growth," Businesis Week, November $7_{2} 19 \% \mathrm{~m}$, p. 14 and "A Reader Writes: Euromarket Has Gained Control of U.S. Money Supply," The Money Manager, October 17, 1.977, p. $8 . \mathrm{M}_{1}$ is defined as demand deposits plus currency and includes holdings of these by foreign govermments, finarcial institutions, and individuals, as well as those of U.S. residents. 3 Earodollar deposits are therefore not U.S. bollars owned exchusively by foreigners. It shonld also be noted that Ento- claims are owned not only by foreign citizens and corporations but also by U.S. citizens and corporations, international organizations, and by national governments.

Funds can be transferred from a U.S. bank to a Eurodollar account for a variety of reasons. It may be that a U.S. citizen sees that a higher rate of interest can be eamed at a Eurobank (any bank outside the U.S. which has dollar-denominated assets and liabilities), or that a foreign corporation receives a check from a U.S. corporation in payment for goods, and decides to keep those funds in dollars, although at a bank outside the U.S.

In any event, the Eurobank now owns a demand deposit at a U.S. bank. The effect on the U.S. banking system of establishing the Eurodollar deposit has been to transfer ownership of a demand deposit from a U.S. resident to a Eurobank. Thus, the "creation" of the Eurodollar deposit has no effect on the money stock of the U.S.

The Eurobank receiving the deposit can subsequently extend dollar loans based on the demand deposit which it holds at a U.S. bank, maintaining some portion of the demand deposit at the U.S. bank as "precautionary reserves."

dollars are dollar-denominated claims on banks outside the U.S., not bundles of U.S. currency. (Just as the bulk of the U.S. money stock comprises claims on banks in the U.S., and not actual currency in circulation.)

3There is no reason in principle why the loan should be a dollat loan; it could be in some other currency. We have dealt only with a dollar loan so as to focts on the uarticular point at issue. 
The loan might take the form of a dollar loan to a European corporation, executed by transferring some portion of the deposit which the Eurobank holds in the U.S. to a demand deposit account held by the borrowing corporation at the same or another U.S. bank. The net effect on the U.S. banking system of this Eurodollar loan again would be a transfer of ounership of demand deposit accounts without changing the level of total U.S. demand deposits.

The foreign-based corporation receiving the Eurodollar loan in this example conld use the demand deposit account which it now owns in the U.S. to make final payment for goods and services purchased in the U.S. Alternatively, it could decide to deposit part or all of the Eurodollar loan in another Eurobank. In this case, the Eurobank could extend further Eurodollar loans, pending the use of the funds by the corporation.

The "creation" of Eurodollar deposits is thus a process identical to the "creation" of bank deposits in the U.S. banking system. Eurobanks are, insofar as they deal in dollars, part of the U.S. banking system, just as Missouri banks are, in that all require U.S. dollar deposits before they can grant U.S. dollar loans. ${ }^{4}$

In the case of the Eurodollar market, the expansion of Eurodollar deposits is based, in effect, on the transfer of ownership of demand deposits held by Eurobanks at U.S. banks." The total level of demand deposit liabilities held by the U.S. banking system, however, is not changed by the multiple expansion of Eurodollar deposits. "The process is identical to that which would follow if a deposit is withdrawn from one bank in the U.S. and transferred to another. The first bank would lose reserves and have to reduce its earning assets, for example its loans, while the second

this was first pointed out by Miton Ftiedman, "The EuroDollar Market: Some First Principles," this Review (July 1971), pp. 16-24, and later re-emphasized by John Williamson, "Review of The Economics of the Eura-Currency System by George W. McKenzie," The Manchester School (March 1977), pp. 86-88, and by Michael J. Hamburger and Geoffrey E. Wood, "Interest Rates and Monetary Policy in Open Economies" (paper presented to Federal Reserve Committee on Financial Analysis, November 16-18, 1977).

OOnly to the extent that Eurobanks hold "precautionary reserves" in the form of time deposits, rather than demand deposits, at U.S. banks will U.S. M change. This change in $\mathrm{M}_{\mathrm{I}}$ could, however, be entirely offset by Federal Reserve open market operations, as described later in this paper.

Whis abstracts, for expository simplicity, from the existence of Gifferent reserve requirements at clifferent banks. For a discussion of the consequence of this, see Albert $\mathrm{E}$. Burger and Robert H. Rasche, "Revision of the Monetary Base," this Review (July 1977), pp. 13-23. bank would acquire reserves and thus be able to expand loans. In the absence of a change in the monetary base on which the loans are pyramided, the total of loans which could be extended will not change.

In summary, the reason why movements between $\mathrm{M}_{1}$ and Eurodollars do not affect $\mathrm{M}_{1}$ is that one acquires a Eurodollar asset by supplying U.S. dollars. This transfers the ownership of some U.S. dollars, but does not affect the total.

One qualification is in order. A U.S. bank may have the ability to affect demand deposits, and hence $\mathrm{M}_{1}$, by changing the composition of its liabilities between demand deposits and funds borrowed from the Eurodollar market. An example of this would be when a large bank in the U.S., which was holding a demand deposit due to a bank in London, has that deposit converted to a loan from that bank. The immediate effect of this is a fall in $M_{1}$, but it does release reserves, since the reserve requirement on Eurodollar borrowings is 4 percent, while that on demand deposits is 16.25 percent at the largest banks. If the entire amount of reserves which have been freed is used to make loans which subsequently become demand deposits at banks with a smaller marginal reserve requirement, and these banks then extend loans which remain as demand deposits at banks with the same reserve requirement as themselves, an expansion of $\mathrm{M}_{1}$ is possible. ${ }^{7}$ However, as Eurodollar transactions tend to be concentrated in the larger banks, such an effect is not likely. But even should such an effect occur, as is shown below it can be fully offset by Federal Reserve action.

So far we have examined the effect of an owner of a part of $\mathrm{M}_{1}$ moving his deposit to a Eurobank. It is also necessary to consider a movement from an interest earning asset, such as a time deposit, to a Eurodollar deposit. In this case, the dollars held as time deposits would initially be shifted into demand deposits, and subsequently transferred to a Eurodollar deposit. The initial shift from a time to a demand deposit would increase $M_{1}$, just as would a shift from a time deposit to a demand deposit made for any

TCurrently, reserve requirements on net demand deposts which apply to member banks ate: $7 \%$ for banks having less than $\$ 2$ million in demand deposits, $9.5 \%$ for $\$ 2-\$ 10$ million in demand deposits, $1.75 \%$ for $\$ 10-100$ million in demand deposits, $12.75 \%$ for $\$ 100-400$ million in demand deposits, and $16.25 \%$ for banks having demand deposit liabilities in excess of $\$ 400$ million. It car be seen that for the effect on $M_{1}$ of a deposit moving from one bank to another to be nontrivial, the deposit would have to move from a bank with deposits in excess of $\$ 400$ million to one with deposits of less than $\$ 10$ million. 
other reason. However, this increase in $\mathrm{M}_{1}$ could also be fully offset by Federal Reserve open market operations, that is, by the purchase or sale of U.S. Govermment securities by the Federal Reserve.

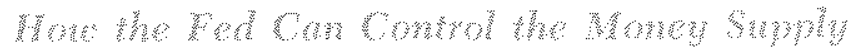

It is useful to set out the sequence of events through which Eurodollar transactions are viewed as affecting $\mathrm{M}_{1}$. Once that has been done, it can be seen how the Federal Reserve, should it choose to do so, can conteract these effects. The sequence of events through which Eurodollar market transactions are supposed to result in increases in the U.S. money supply can be set out as follows. The continued decline in the foreign exchange value of the U.S. dollar has, the argument runs, encouraged Eurodollar holders to convert their Furodollars into Deutsche marks, Swiss franos, French francs, etc. Thus, as the value of the dollar in terms of most European currencies declines, foreigners holding dollar-denominated deposits in European banks ". . have been selling dollars to buy German marks and the like. ..."

European central banks, it is further asserted, take part in these transactions by selling their domestic currencies for U.S. dollars. Some portion of the increased dollar balances held by European central banks is then used to purchase U.S. Treasury securities from U.S. residents. These U.S. residents subsequently deposit the proceeds from these sales in their checking accounts. As a result U.S. demand deposits, and consequently $M_{1}$, have been increased.

Now, as was shown above, that analysis is incomplete. It neglects that the Eurodollars had as their base deposits within the U.S. banking system. When holders of Eurodollar deposits instruct the banks at which these deposits are held to convert the deposit from dollars to some other currency, the effect may indeed be to transfer the ownership of a U.S, demand deposit from the Eurobank to a foreign central bank. If it so desires the foreign central bank may then use this U.S. demand deposit to purchase U.S. Government securities. This transaction would transfer ownership of the U.S. demand deposit from the foreign central bank to the U.S. residents from which the securties were purchased.

Thus, Eurodollar deposit holders can convert these deposits into foreign currencies, ultimately resulting in foreign central bank purchases of U.S. Govemment

sBusiness Week, p. 14.
Securities, with no substantial change in the level of U.S. demand deposits occurring. Insofar as it affects $M_{1}$, the process in the end result is exactly like that of one U.S. resident buying U.S. Govemment securities from another; no matter how many internediate steps there are, there is ultimately no effect on $\mathrm{M}_{1}$, except in the case where reserves are released by the transactions, and that effect is, as shown above, minor.

Even should that minor effect occur, the Federal Reserve can offset it in two ways. ${ }^{9}$

First, when the Eurodollar holders sell their dollars, they do not go along and offer them to foreign central banks; rather, they sell them on the foreign exchange market to whomever will buy them. There is nothing to stop the Federal Reserve System from using its foreign exchange reserves to buy the dollars at that point, thus bringing the process to a quick end, for there would be no increase in foreign central banks' holdings of dollars. Altematively, the "reappearance" of Eurodollar deposits as U.S. demand deposits could be offset domestically. Changes in the U.S. money supply can be offset by Federal Reserve open market operations. In this present case, the Federal Reserve System would sell some of its holdings of Government securities. This action would reduce both bank reserves and $\mathrm{M}_{1}$.

Thus, any increase in the U.S. money supply which might conceivably result from investors converting Eurodollar deposits into foreign currency holdings can readily be offset by the U.S. monetary authorities. They can offset the increase in $M_{1}$ by operating either in the foreign exchange market or in the market for U.S. Govermment debt, or both. Far from being unable to offset this monetary impulse, the Federal Reserve actually has two instruments by which it can do so.

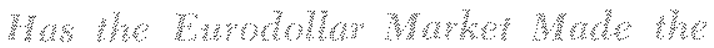 Bow Wras}

It is sometimes claimed that the dollar's recent weakness has been due to self-fulfilling expectations

9t is useful to note that even if the Federal Reserve does not
try to of set these effects on $\mathrm{M}_{1}$, they may be only transitory.
Suppose the Federal Reserve is controlling an interest rate,
such as the Federal funds rate. Suppose further that there is
an increased desire to borrow dollars and sell them for some
other cunency. This increased denand for credit raises interest
rates. In attempting to offset this rise the Federal Reserve
increases bank reserves by buying Treasury bills. The money
supply thereby expands. Suppose that those who sell foreign
currency to dollar holders wish to buy U.S. Treasury bills. 
operating in the Eurodollar market. The argument for this position is that the dollar has been weak only because $M_{1}$ has been growing unduly rapidly, and that $M_{1}$ has been growing because of Eurodollar transactions undertaken in the expectation of further weakness of the dollar.

Even if the argument that Eurodollar transactions could substantially affect $M_{1}$ were correct, it is ensy to see that the Federal Reserve can offset such influences on the U.S. money stock. Eurodollar transactions cannot be blamed for the slide in the U.S. dollar's foreign exchange value.

This increased demand for Treasury bills lowers interest rates. The Federal Reserve now sees interest rates falling, and reacts by supplying Treastry bills, thus offsetting its original action.

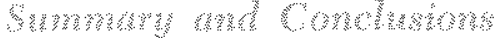

The net effect of transactions in the Euromarket on the U.S. money supply is virtually negligible. Transactions in the Eurodollar market cannot have contributed significantly to the recent growth in $M_{1}$. Further, the arguments in the second section of this paper show that the U.S. monetary authorities have the ability to offset whatever effects on $M_{1}$ Eurodollar transactions may have. The existence of that market has not reduced the ability of the Federal Reserve System to control the U.S. money stock. It therefore also follows that any claim that the foreign exchange value of the U,S. dollar is declining becanse of selffulfilling expectations operating through the Eurodollar market is totally false.

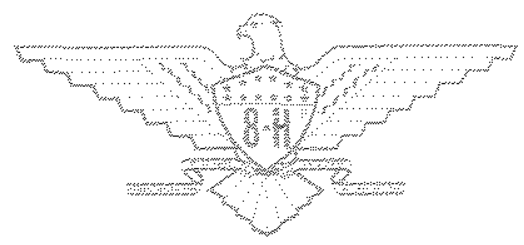

